\title{
Insecticides Residue in the Centre of Paddy Field in Musi Rawas, South Sumatera, Indonesia
}

\author{
Wartono $^{1,2}$, Rujito. A. Suwignyo ${ }^{3}$, Adipati. Napoleon ${ }^{3}$, and Suheryanto ${ }^{4}$ \\ ${ }^{1}$ Student, Doctoral Study Program in Environmental Science, Universitas Sriwijaya, Palembang- \\ Indonesia \\ ${ }^{2}$ Lecturer, Agriculture Faculty, Musi Rawas University, Indonesia \\ ${ }^{3}$ Lecturer, Faculty of Agriculture, Universitas Sriwijaya, Palembang-Indonesia \\ ${ }^{4}$ Faculty of Mathematical and Natural Science, Universitas Sriwijaya,Palembang- Indonesia
}

\begin{abstract}
Currently, the production of consumable- rise relies on rice fields especially technical irrigated rice fields. In increasing rice production, the use of insecticides become the main option to control the pest attacks.This condition generates the environmental pollution of insecticide residues on the field- soil. The most widely used- pesticides by the lowland rice farmers are insecticides or poisons to control plant pests. The active ingredients contained in insecticides are methomyl, fipronil, buprofezin, and chlorantanipol and others. Each active ingredients have the percentages of $19.20 \%, 16.87 \%, 13.56 \%, 13.32 \%$, and $<10 \%$, respectively. This study aims to detect insecticide residues in the soil generated by the insecticides uses. This research was conducted at the Musi Rawas rice field center which uses insecticides as the pest control. This research was conducted in March 2018 using survey method by taking soil samples on rice fields. Residual analysis was analyzed using Gas Chromatography (GC) in the Environmental Laboratory of the Indonesian Center for Biodiversity and Biotechnology Bogor (ICBB). Laboratory test results detected $0.04 \mathrm{ppm}$ of methomyl as the highest residual content in the sample.Therefore, the result has exceeded the quality standard which is $0.02 \mathrm{ppm}$. Moreover, the soil needs the further remediation to reduce contaminated- pesticides.
\end{abstract}

\section{Introduction}

Currently, the production of consumable- rise relies on rice fields especially technical irrigated rice fields. In increasing rice production, the use of insecticides become the main option to control the pest attacks. This condition generates the environmental pollution of insecticide residues on the field- soil. Pesticides are applied to prevent, reduce or control pests that potentially reduce the number of productivities of rice per hectare, and even cause the crop failure known aspuso[1]. The loss of production yield could be done by attacking of plant disturbing organisms and pestwhich reduce $\pm 30 \%$ and $20-25 \%$ of yield production every year [2]. 
Insecticides are one of pesticide that is widely used by local farmer in wetland rice field to control plant disturbing population. The use of insecticides has the highest rank in the cultivation of lowland rice in Musi Rawas. The insecticides uses varies with the type of insecticides in which the pest control type become the highest number of uses $(45.83 \%)$ compared to herbicide, fungicide, and rodenticide .

Improper use of insecticides can endanger the environment including ecology, economic, and social. The use of insecticides has exceeded the recommendations dosages which could generate the pest immunity, Moreover, the increasing number of insecticide uses could affect the qualities of soil, water, and plant.

In Musi Rawas, some sub-districts such as Tugu Mulyo, Purwodadi, Sumber Harta, Muara Beliti, and Megang Sakti are the center of paddy cultivations. The percentages of insecticide use in Musi Rawas from high percentages to low percentage were $16.88 \%$ (regent), 13.88\% (apllaud), 13.32\% (Virtako), 11.35\% (danke), 9.50\% (decis), 8.70\% (maneuver), 7.85\% (lannet), 7.48\% (kejora), 7.18\% (exocet), 3.06\% (serva), and 1.13\% (curater)

In Musi Rawas, the local farmers use different types of insecticides for controlling the pest even the types of pest attacking the rice crop are the same. The common types of usedinsecticide are carbamate, pyrethroid, phenyl pyrazole and buprofezin.

Reported that the highest use of insecticides is located in the sub-district of sumber karya, sumber rejo, and air lesing. Furthermore, the most active ingredient contained in insecticides detected in this sub-district are methomyl, fipronil, and buprofezin.

The continuously use of insecticide with high frequency could generate residues on the soil. The insecticide residues in the soil are affected by soil organic matter content. The high soil organic matter content causes the high insecticide residues in the soil in which the residues tend to accumulate on topsoil layer soil at a depth of 10-20 cm. In the topsoil layer, there is quite enough organic material which easily absorbs the insecticide and generate it as residues which pollute the environment .

\section{Materials and Methods}

This research was conducted in March 2018 using survey method by taking soil samples on rice fields. Residual analysis was analyzed using Gas Chromatography (GC) in the Environmental Laboratory of the Indonesian Center for Biodiversity and Biotechnology Bogor (ICBB). Soil samples are taken based on the results of the survey where are in areas with the highest number of doses and the number of insecticide applications. 5 points of soil samples were taken using a diagonal system by drilling at a depth of $20 \mathrm{~cm}$ with a sample of $1 \mathrm{~kg}$ of soil. Furthermore, the samplesaremixed to form the composite sample.

Pesticide residue analysis was carried out at the Bogor Indonesian Center for Biodiversity and Biotechnology (ICBB) Laboratory using Gas Chromatography (GC).The residual concentration in the sample is calculated based on the formula (Ohsawa et al., 1985):

\section{Results and Discussions}

The percentage of the highest use of active ingredients contained in insecticides is methomyl with $19.20 \%$ of lannets followed by regent with $16,87 \%$. The other active ingredients are buprofezin with $13.56 \%$ of applaud and $13.32 \%$ of klorantanipol insektisida virtako. In addition, the other active ingredients are still below $10 \%$. 
Table 1. Percentage of Active Insecticides uses in MusiRawas Regency

\begin{tabular}{|c|c|c|c|}
\hline No & Insecticide & Active ingredient & \multirow{2}{*}{$\%$} \\
\hline 1. & Danke & Methomil & \multirow{2}{*}{19.20} \\
\hline 2. & lannet & Methomil & \\
\hline 3. & Regent & Fipronil & 16.87 \\
\hline 4. & Applaud & Buprofezin & 13.56 \\
\hline 5. & virtako & Klorantranilipol & 13.32 \\
\hline 6. & Decis & Deltamethrin & 9.50 \\
\hline 7. & Manuver & Dimehipo & 870 \\
\hline 8. & Kejora & alfasipermetrin & 7.48 \\
\hline 9. & exocet & Sipermetrin & 7.18 \\
\hline 10. & Serva & Carbofuran & \multirow{2}{*}{4.19} \\
\hline 11. & Currater & Carbofuran & \\
\hline
\end{tabular}

The use of insecticidal active ingredients that are widely used by farmers is to control the type of brown planthopper (Nilaparvata lugens) and spread almost throughout the districts in Musi Rawas Regency. The active ingredients that can be used to control these pests are buprofezin, fipronil, abamectin, and imidacloprid. The most widely used active ingredient in Musi Rawas Regency is buprofezin, fipronil, and methomyl[3].

In the studied area, the excessive use of insecticides on rice plants initiate the pest blasts indicated as the explosion of brown planthopper attacks. Intensive use of insecticides in rice fields increases the female planthopper population and kill natural enemies that have the function as regulators of the balance of ecosystems in rice fields [4].

In Musi rawas, the average dose, application frequency, and types of used- insecticide used have exceeded the recommended doses. The use of pesticides that do not comply with recommendations will affect environmental pollution. The study has proven that the excessive use of pesticides can contaminate water and soil indicated by the increasing of detected- metal content in water and soil [5]. According to [1], the exceed dosage of insecticides could kill the natural enemies of pest which generate adverse side effects.Untargeted- living organism could die due to poisoning whereas the other living organism around plants plays an important role in maintaining the ecosystem. The natural enemies could die resulting the poisoning soil and water.

Several insecticides such as danke, decis, lannate, kejora, and sherpa are not intended for rice plants . This is contrary to the Government Regulation Republic of Indonesia Number 6 of 1995 concerning Plant Protection that pesticides use must be in accordance with the type of plant commodity and the way of life of disturbing organisms.Before using pesticides, farmers should know the types of pesticides that are in accordance with the commodity and the type of pest that attacks the plant [6]. Most of the increase in pest resistance to pesticides in rice fields is caused by the inappropriate application of insecticides without being based on knowledge of plant pest organisms (PPO) that attack and use of pesticides in accordance with their designation.Generally, farmers choose the type of pesticide based on information from pesticide stores. Farmers do not understand the techniques for using pesticides safely and effectively.

Some classes of insecticides are widely used by rice farmers including pyrethroids, carbamates, neritoxins, phenyl pyrazole, thiadiazine, and organophosphate. Table 3.2 shows the percentage of insecticides that are widely used by rice farmers in Musi Rawas. 
Table 2. Percentage of used- insecticidegroups in MusiRawas Regency.

\begin{tabular}{|c|c|c|}
\hline No & $\begin{array}{c}\text { Type of } \\
\text { insecticide }\end{array}$ & $\mathbf{\%}$ \\
\hline 1. & Piretroid & 24.16 \\
\hline 2. & Carbamate & 22.26 \\
\hline 3. & Neritoksin & 22.02 \\
\hline 4. & Fenil pyrazol & 16.88 \\
\hline 5. & Tiadiazin & 13.56 \\
\hline 6. & Organoposfat & 1.12 \\
\hline & Total & 100 \\
\hline
\end{tabular}

Based on Table 4.2, the class of used- pesticides are used to control caterpillars, stink bugs and leafhoppers. The use of various types of insecticides can cause adverse effects on the environment.The effect of using pesticides which do not follow the recommendations would generate the resistant to plant pest organisms and increase the pest population or born new pest organism after applying the pesticide [7].

Table 3.3 shows the laboratory test result of soil fertility and insecticide residues.

Table 3. Soil characteristic in the studied area

\begin{tabular}{|c|c|c|c|c|c|c|}
\hline \multirow{2}{*}{ No } & \multirow{2}{*}{\multicolumn{2}{|c|}{ Parameter }} & \multirow{2}{*}{ Unit } & \multicolumn{3}{|c|}{ Location } \\
\hline & & & & Air Lesing & SumberRejo & SumberKarya \\
\hline 1. & \multicolumn{2}{|c|}{ C-Organic } & $\%$ & 2.87 & 5.32 & 4.54 \\
\hline 2. & \multicolumn{2}{|c|}{ N-total } & $\%$ & 0.30 & 0.40 & 0.37 \\
\hline 3. & \multicolumn{2}{|c|}{ C/N Ratio } & - & 9.54 & 13.25 & 12.41 \\
\hline 4. & \multicolumn{2}{|c|}{$\mathrm{P}_{2} \mathrm{O}_{5}$ available } & ppm & 34.00 & 109.75 & 30.15 \\
\hline 5. & \multicolumn{2}{|c|}{$\mathrm{K}_{2} \mathrm{O}$ available } & $\mathrm{ppm}$ & 111.08 & 145.93 & 133.34 \\
\hline 6. & \multicolumn{2}{|c|}{$\mathrm{P}_{2} \mathrm{O}_{5}$ Potential } & ppm & 180.50 & 227.14 & 245.39 \\
\hline 7. & \multicolumn{2}{|c|}{$\mathrm{K}_{2} \mathrm{O}$ Potential } & $\mathrm{ppm}$ & 132.57 & 178.83 & 181.01 \\
\hline 8. & \multicolumn{2}{|c|}{ Cation Exchange Capacity } & $\mathrm{Cmol} / \mathrm{kg}$ & 50.11 & 63.68 & 64.27 \\
\hline 9. & \multicolumn{2}{|c|}{ Water content } & $\%$ & 6.17 & 7.98 & 7.75 \\
\hline \multirow{2}{*}{10.} & \multirow{2}{*}{$\mathrm{pH}$} & $\mathrm{H}_{2} \mathrm{O}$ & - & 5.97 & 5.76 & 5.17 \\
\hline & & $\mathrm{KCl} 1 \mathrm{~N}$ & - & 4.73 & 4.35 & 4.14 \\
\hline \multirow{3}{*}{11.} & \multirow{3}{*}{$\begin{array}{c}\text { Texture of } 3 \\
\text { fractions }\end{array}$} & Sand & $\%$ & 33.63 & 26.99 & 22.90 \\
\hline & & Clay & $\%$ & 57.45 & 53.51 & 55.78 \\
\hline & & Dust & $\%$ & 8.92 & 19.50 & 21.32 \\
\hline
\end{tabular}

Soil characteristics of the study site, Physico-chemical properties of soil, clay mineralization, and soil classification indicate that the content of organic matter (COrganic) from this soil is slightly poor while the clay content is generally high $(>50 \%)$.

Based on the results of the insecticide residue test, the insecticide residue of methomyl is detected in air lesing which is $0.04 \mathrm{ppm}$ and in sumber rejo and sumber karya which are $0.01 \mathrm{ppm}$ for both places. For fipronil, there is only $0.01 \mathrm{ppm}$ detected in air lesing. Furthermore, buprofezin is not detected in all studied area. The result shows that the concentration of insecticide residue is relatively small but it could accumulate in soil if the use of insecticide is continuously used with high frequency. The accumulation generates the soil pollution in the agricultural land.

Laboratory test results show that methomyl become the highest residual content found in the sample. this is because the recommended- active ingredients regulated by the government is biodegradable and easy to absorb due to hydrolysis. Moreover, Pesticides entering the soil will go through 7 processes which is volatilization into the atmosphere without chemical changes, soil adsorption, lost through leaching;react chemically in soil or 
soil surface, biodegradable, carried away by erosion and run-off into the river; andenter through the roots, absorbed by clay minerals and then undergo biological and chemical degradation.Pesticides which are given to plants will also go through volatilization, exposure to radiation, decompose by photodecomposition, and lost through leaching and run-off [8].

The results show that regent becomesthe highest used- insecticide in the MusiRawas. The highest use is in the Megang Sakti sub-district of Sumber Rejo village which is 35, $50 \%$.

Table 4 shows the laboratory test result of the sample which detects the insecticide residues.

Table 4. Laboratory test result of activated- insecticides compound

\begin{tabular}{|c|c|c|c|c|c|c|}
\hline No & Parameter & Method & Unit & $\begin{array}{c}\text { Desa Air } \\
\text { Lesing }\end{array}$ & DesaSumberRejo & DesaSumberKarya \\
\hline & Pesticide residue & & & & & \\
\hline 1. & Methomyl & GC & ppm & 0,04 & 0,01 & 0,01 \\
\hline 2. & Fipronil & GC & ppm & 0.01 & 0,00 & 0,00 \\
\hline 3. & Buprofezin & GC & ppm & 0,00 & 0,00 & 0,00 \\
\hline
\end{tabular}

Based on the results of laboratory analysis in table 3.3, methomyl is detected in soil with the characteristic of low $\mathrm{C}$-organic content and high clay content. This is because organic matter, clay content, $\mathrm{pH}$, etc. affect the degradation of pesticides in the soil (Chowdhury et al., 2008). In aerobic conditions, methomyl has a half-life of more than 50 days with a depth of $15-30 \mathrm{~cm}$ from the soil surface and it is degraded and form carbon dioxide. This compound is relatively stable against hydrolysis under conditions of neutral and acidic.Under normal conditions, methomyl is degraded with a half-life of 30 days, but with soil texture conditions. the location of the insecticide remains detectable high enough above the environmental quality standard. Methomyl degradation will be slow in the $\mathrm{pH}$ range 4-6 while $\mathrm{pH}$ 7-9 will accelerate degradation of methomyl by the bacterium Paracoccus sp (Xu et al., 2009).

The methomyl active ingredient with the chemical formula $\mathrm{C}_{5} \mathrm{H}_{10} \mathrm{~N}_{2} \mathrm{O}_{2} \mathrm{~S}$ is grouped in the oxime carbamate insecticide which controls a broad spectrum of pests for arthropods such as spiders, fleas, moths, flies, beetles, aphids, leafhoppers, and mites which are often found in various plants. These insecticides have toxicity properties that can contaminate groundwater and surface water generating biotic environmental toxicity (Strathmann and Stone, 2001, Fan and Liao, 2009; Fulekar et al. , 2009).

Soil characteristics of the study locations such as physical-chemical properties, clay mineralization, and soil classification showed that the content of organic matter $(\mathrm{C}$ Organic) from this soil was slightly worse while the clay content was generally high (> $50 \%$ ). These characteristics exhibit the strong adsorption between the pesticide residue and soil.The adsorptionproperties of pesticides on soil particles is influenced by the type of pesticide, moisture, $\mathrm{pH}$, and soil texture. For example, the pesticide adsorption processon clay or soil with high organic matter will run stronger, whereas on sandy soil, the adsorption is quite low.

\section{Conclusion}

Based on the study, we could conclude some points shown below: 1) the most widely used type of insecticide by wetland farmers in Musi Rawas Regency is insecticides with methomylas the active ingredients, 2)the insecticide residue of methomyl is detected in air 
lesing which is $0.04 \mathrm{ppm}$ and in sumber rejo and sumber karya which are $0.01 \mathrm{ppm}$ for both places. For fipronil, there is only $0.01 \mathrm{ppm}$ detected in air lesing. However, buprofezin is not detected in all studied area.

\section{References}

1. Parveen, S. and N. Nakagoshi. Journal of International Development and Cooperation 8, 1 (2001)

2. Zhoua. X, Shia. X, Zhanga. L, Zhoua. Y. J. Energy Procedia 16 (2012)

3. Ohsawa, K, S, Hartati, S, Nugrahati, H, Sastrohamidjoyo, K, Untung, N, Arya, K, Sumiartha dan S, Kuwatsuka, Residue analysis of organochlorin and organophosphorus pesticides in soil, water and vegetabels from central Java and Bali, ecol (impact of IPM in Indonesia, 1985)

4. Saenong, M. S. Beberapa Senyawa Pestisida yang Berbahaya. Prosiding Seminar Ilmiah dan Pertemuan Tahunan PEI dan PFI XVIII Komda Sul-Sel (2007)

5. Kesuma S.D, Hariyadi, dan Syaiful Anwar. Jurnal Pengelolaan Sumberdaya Alam dan Lingkungan 5, 1 (2015)

6. Djojosumarto, P.Teknik Aplikasi Pestisida Pertanian (PT. Agromedia Pustaka, Jakarta, 2009)

7. Reddy, G.V.P. J. Pest Management Science 67, 8 (2011)

8. Ramesh. A, Tanabe. S. Murase. H, Subramanian. A. N, and Tatsukawa. J. Environmental Pollution 74 (1991) 